\title{
TROPICAL HOUSE GECKO (Hemidactylus mabouia) PREDATION ON BROWN SPIDERS (Loxosceles intermedia)
}

\author{
RAMIRES E.N. ${ }^{1}$, FRAGUAS G.M. ${ }^{1}$ \\ ${ }^{1}$ Curso de Ciências Biológicas - Universidade Tuiuti do Paraná, Curitiba, Paraná, Brasil.
}

\begin{abstract}
Brown spiders (Loxosceles spp.) are venomous arachnids, successfully adapted to urban habitats in Brazil. Loxoscelism became a serious public health problem in Paraná State, especially at the capital Curitiba, where the most abundant species is Loxosceles intermedia. Hemidactylus mabouia (Gekkonidae) lizards are synanthropic predators of arthropods. In this paper, we describe the predatory behavior of the Tropical House Gecko $\mathrm{H}$. mabouia on L. intermedia under laboratory conditions. Twelve geckos were observed, and all of them fed on brown spiders ( $\mathrm{n}=123$ observations). The attack consisted of a fast run followed by one bite on the spider's abdomen or legs. The geckos did not attack L intermedia anterior body parts, probably due to the fangs present in this region. Two Hemidactylus individuals were killed by L. intermedia bites: during a predatory encounter, and by an induced bite on a restrained lizard. The observations summarized in this paper show that $H$. mabouia could be used in the biological control of Loxosceles populations in human dwellings. However, additional field studies are necessary to quantify the impact of $H$. mabouia predation on urban populations of $L$. intermedia and other species of the same genus.
\end{abstract}

KEY WORDS: Hemidactylus mabouia, predatory behavior, Loxosceles intermedia, Sicariidae, Araneism, Gekkonidae, biological control.

\section{CORRESPONDENCE TO:}

E. N. RAMIRES, Curso de Ciências Biológicas, Universidade Tuiuti do Paraná - Rua Marcelino Champagnat, 505, 80710-250, Curitiba, PR, Brazil. Phone/fax: 55413317843.

Email: eduardo.ramires@utp.br 
E. N. Ramires, G.M. Fraguas. TROPICAL HOUSE GECKO (Hemidactylus mabouia) PREDATION ON BROWN SPIDERS (Loxosceles intermedia). J. Venom. Anim. Toxins incl. Trop. Dis., 2004, 10, 2, p.186.

\section{INTRODUCTION}

Tropical House Gecko (Hemidactylus mobuia) originated in Africa, and nowadays is found all over Brazil and South America in natural habitats and, more frequently, in human dwellings $(9,10)$.

In most cases, brown spider (genus Loxosceles) bites in humans can cause dermonecrotic lesions and, in some occasions, severe general symptoms (4). These spiders successfully adapted to the urban habitat in many countries, including Brazil, where Loxoscelism became a serious public health problem in Paraná State, especially in the capital Curitiba (8). In 2003, 3,634 cases of people bitten by brown spiders were reported in Curitiba - data from Paraná State Health Department (Secretaria Estadual de Saúde do Paraná). This number is much higher than the ones reported in any other region of the World. The most abundant species of spider in Curitiba is L. intermedia (5), and effective integrated pest control technologies for its populations are still in development in this city.

Brown spiders and house geckos are both synanthropic animals that present nocturnal activities. Hemidactylus mabouia is a generalist predator of arthropods (11).

In this paper, we studied the predation of $H$. mabouia on L. intermedia under laboratory conditions.

Hemidactylus mabouia individuals (snout-vent length range: 3.2 to $6.0 \mathrm{~cm}$ ) were kept on the laboratory walls in experimental arenas made with Styrofoam frames (135 X $75 \mathrm{~cm}$ and 100 $\mathrm{X} 55 \mathrm{~cm}, 10 \mathrm{~cm}$ height) glued with industrial silicone and covered with translucent cloth. Water was provided in small plastic pots. Subadult and/or adult male and female $L$. intermedia spiders (cephalotorax width between 2.7 and $3.7 \mathrm{~mm}$ ) were offered to the geckos. Temperature was kept between $18^{\circ} \mathrm{C}$ and $25^{\circ} \mathrm{C}, 12: 12 \mathrm{~h}$ (L:D) photoperiod; and the observations were made from 09:00 am to 08:00 pm, under fluorescent light (two 40W tubes 4.0-m high).

The spiders were individually introduced into the experimental arena, and continuously observed during the next $30 \mathrm{~min}$. If no predatory encounter happened during this period or in further occasional observations, the next day, the spider was searched in the cage. However, 
E. N. Ramires, G.M. Fraguas. TROPICAL HOUSE GECKO (Hemidactylus mabouia) PREDATION ON BROWN SPIDERS (Loxosceles intermedia). J. Venom. Anim. Toxins incl. Trop. Dis., 2004, 10, 2, p.187.

when predation occurred, another brown spider was introduced immediately after the ingestion of the previous one.

The twelve geckos observed fed on brown spiders ( $\mathrm{n}=123$ observations). One of them (5.95 cm snout-vent length) ingested three L. intermedia spiders in 30 minutes, and six in one day.

When preying on L. intermedia during the 30 minutes of observation ( $\mathrm{n}=106$ observations), the geckos used to lift the head towards the spider, which has just been introduced into the experimental arena, and started walking slowly approaching Loxosceles, generally facing its lateral or posterior body regions (Figure 1A). Some centimeters from the spider, the geckos used to stop, and sometimes, licked their labial scales. On two occasions, we observed geckos hitting the tail against the cage walls several times. The attack consisted of a fast run followed by one bite on the spider's abdomen or legs (Figure 1B). We did not observe any gecko attacking spider's anterior body parts, probably due to the fangs present in this region. The gecko with the restrained spider in its mouth could hit the head against the substrate several times. Autotomy of legs from Loxosceles spiders occurred many times, but this behavior was unsuccessful in protecting the spiders in all the observations.

When predation did not occur during the observation period ( $\mathrm{n}=17$ observations), the gecko only moved the head towards the introduced Loxosceles. The spider could touch the gecko's body with the front legs, staying with one or more legs in contact with the gecko for about ten minutes. During this time, the Hemidactylus normally remained motionless. The spider used to escape immediately after any movement made by the gecko. In some cases, there was no contact between Hemidactylus and Loxosceles, and in some other observations, the spider passed in front of the gecko several times but the lizard did not react. Only 3 out of the 17 spiders that were not attacked during the 30 -minutes observation period were found alive the next day after the introduction into the experimental arena.

One of the geckos (5.95 cm snout-vent length) was found dead the day after the introduction of a large male L. intermedia, which survived the encounter but autotomized two legs. Observations with a stereomicroscope revealed signs of a spider bite near the gecko's head. In order to test the action of Loxosceles intermedia venom on Hemidactylus, an adult female $L$. intermedia was restrained by its legs and pressed against the front legs region of an immobilized gecko (5.40 cm snout-vent length). The movement of the spider cheliceral fangs 
E. N. Ramires, G.M. Fraguas. TROPICAL HOUSE GECKO (Hemidactylus mabouia) PREDATION ON BROWN SPIDERS (Loxosceles intermedia). J. Venom. Anim. Toxins incl. Trop. Dis., 2004, 10, 2, p.188.

was observed with the help of a magnifying lens. The spider bit once. After that, the gecko was released into the experimental arena, showing locomotion difficulties and staying motionless when touched. It was found dead the next day.

All the observations in this paper were made under artificial light. This fact may have influenced the results, since the geckos could show more promptness to attack under dim light. Nevertheless, it is common to observe H. mabouia active under artificial lights in urban areas, and at early morning and late afternoon in natural habitats (6). Hemidactylus frenatus is considered a biological control agent for mosquitoes, feeding on 63-109 Aedes aegypti mosquitoes per night under laboratory conditions (3). The same study showed that $H$. frenatus predation rate under dark conditions do not significantly differ from that of semi-illuminated conditions, and that geckos could be domesticated to feed under artificial light.

The observations summarized in this paper support the evidence, from occasional field observations and from reports of Curitiba's inhabitants, that $H$. mabouia could be used in the biological control of $L$. intermedia spiders in human dwellings. It is particularly relevant because there are not many predators for brown spiders in anthropic and perianthropic habitats, particularly inside human dwellings $(1,2,7)$, where most loxoscelic accidents happen.

Feces of $H$. mabouia, collected from a house in Curitiba, contained remains of Loxosceles spiders. A study on the feeding habits of $H$. mabouia in natural habitats (11) revealed that spiders are the most important item in its diet.

All pest species could escape from predators that were limiting their population growth (2). This is probably true for $L$. intermedia spiders. This species is not very abundant in natural areas (7). It has some invertebrate predators in urban areas, such as Scytodes globula (Scytodidae) (1), but these are not abundant and may be affected by products used for chemical control of arthropods. Hemidactylus mabouia is a sit-and-wait predator (11), feeding mainly on prey with higher mobility, and L. intermedia is active during the night (7). Additional field studies are necessary to quantify the impact of $H$. mabouia predation on populations of $L$. intermedia and other species of the Loxosceles genus in human dwellings. 


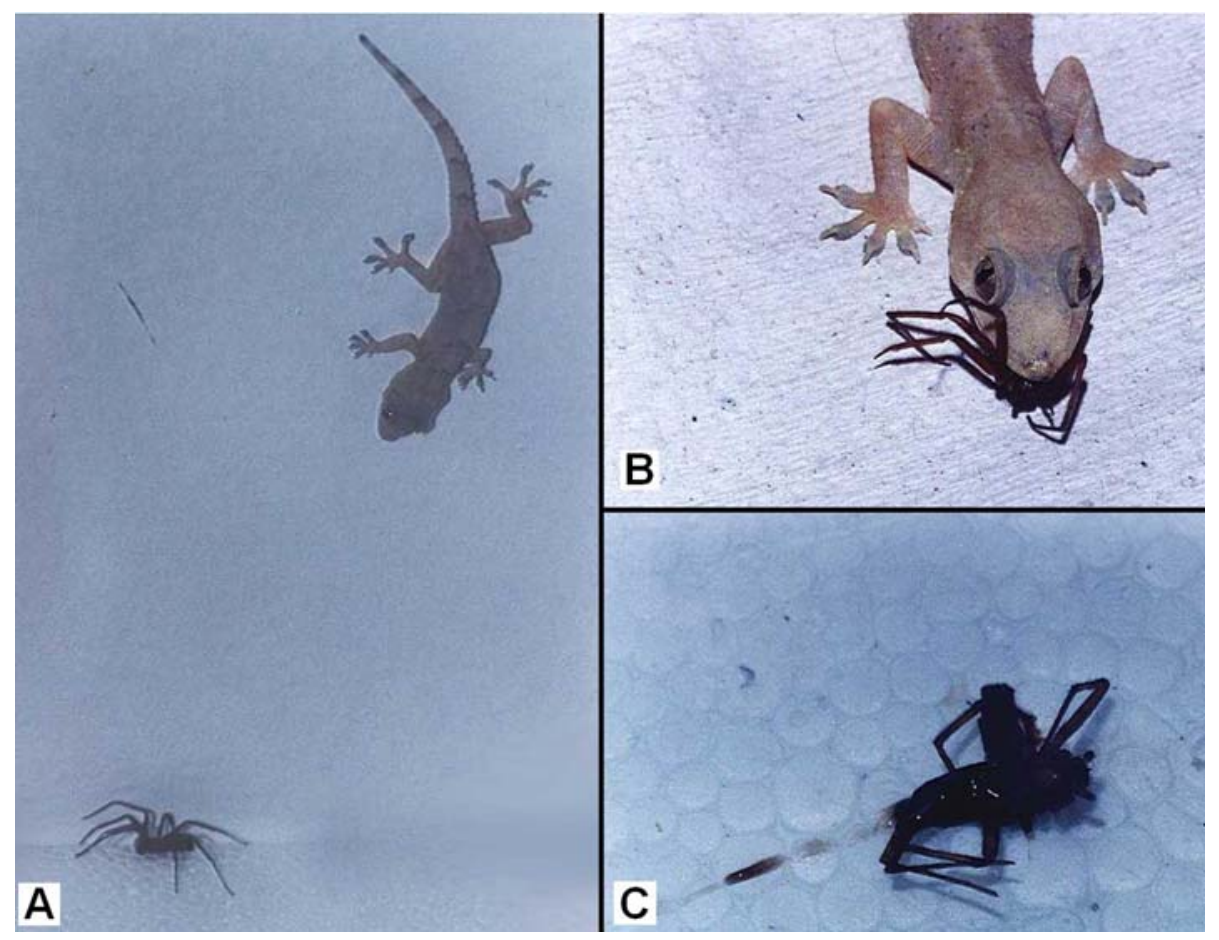

Figure 1. (A): H. mabouia approaching a female L. intermedia spider. (B): H. mabouia ingesting a female $L$. intermedia. (C): L. intermedia female released by $H$. mabouia after disturbance. The spider autotomized two legs and had its abdomen damaged.

\section{REFERENCES}

1 ADES C., RAMIRES EN. Asymmetry of leg use during prey handling in the spider Scytodes globula (Scytodidae). J. Insect Behav., 2002, 15, 563-70.

2 BEGON M., HARPER JL., TOWSEND CR. Ecology: individuals, populations and communities. Boston: Blackwell Scientific Publications, 1990.

3 CANYON DV., HII JL. The gecko: an environmentally friendly biological agent for mosquito control. Med. Vet. Entomol., 1997, 11, 319-23.

4 CARDOSO JLC. Ofidismo-Araneísmo-Escorpionismo. Epidemiologia, Patogenia e Clínica. In: SOERENSEN B. Ed. Animais peçonhentos. São Paulo: Atheneu, 1990. 
5 FISCHER ML. Levantamento das espécies de Loxosceles Heinecken \& Lowe,1832 no município de Curitiba, Paraná, Brasil. Estud. Biol., 1994, 3, 63-88.

6 HATANO FH., VRCIBRADIC D., GLADINO CAB., CUNHA-BARROS M., ROCHA CFD., VAN SLUYS M. Thermal ecology and activity patterns of the lizard community of the restinga of Jurubatiba. Rev. Bras. Biol., 2001, 61, 287-94.

7 RAMIRES EN. Uma abordagem comparativa ao comportamento defensivo, agonístico e locomotor de três espécies de aranhas do gênero Loxosceles (Sicariidae). São Paulo: Universidade de São Paulo, Instituto de Psicologia, 1999. 87p. [TeseDoutorado].

8 RIBEIRO LA., EICKSTEDT VRD., RÚBIO GBG., KONOLSAISEN JF., HANDAR Z., ENTRES M., CAMPOS VAFP., JORGE MT. Epidemiologia dos acidentes por aranhas do gênero Loxosceles Heinecken \& Lowe no Estado do Paraná (Brasil). Mem. Inst. Butantan, 1993, 55, 19-26.

9VANZOLINI PE. Geography of the South American Gekkonidae (Sauria). Arq. Zool. Est. São Paulo, 1968, 17, 85-112.

10 VANZOLINI PE. On South American Hemidactylus (Sauria Gekkonidae). Pap. Avulsos Zool., 1978, 31, 307-43.

11 ZAMPROGNO C., TEIXEIRA RL. Hábitos alimentares da lagartixa-de-parede Hemidactylus mabouia (Reptilia, Gekkonidae) da planície litorânea do norte do Espirito Santo, Brasil. Rev. Bras. Biol., 1998, 58, 143-50. 